\title{
Effects of Black Soybean on Atherogenic Prevention in Hypercholesterolemic Rabbits and on Adhesion Molecular Expression in Cultured HAECs
}

\author{
Pi-Yu Chao ${ }^{*}$, Yuh-Lien Chen ${ }^{2}$, Yi-Chu Lin ${ }^{3}$, Ju-Ing Hsu ${ }^{1,4}$, Kuan-Hung Lin ${ }^{5}$, Yi-Fa Lu ${ }^{4}$, \\ Tien-Joung Yiu', Meng-Yuan Huang ${ }^{7}$, Chi-Ming Yang ${ }^{7}$
}

${ }^{1}$ Department of Food, Health and Nutrition Science, Chinese Culture University, Taipei, Taiwan; ${ }^{2}$ Department of Anatomy and Cell Biology, College of Medicine, National Taiwan University, Taipei, Taiwan; ${ }^{3}$ Institute of Applied Life Science, Chinese Culture University, Taipei, Taiwan; ${ }^{4}$ Department of Nutritional Science, Fu Jen Catholic University, Hsin-Chuang, Taipei, Taiwan; ${ }^{5}$ Graduate Institute of Biotechnology, Chinese Culture University, Taipei, Taiwan; ${ }^{6}$ Tainan District Agricultural Research and Extension Station-Potzu Branch Station, Council of Agriculture, Executive Yuan, Chiayi County, Taiwan; ${ }^{7}$ Research Center for Biodiversity, Academia Sinica, Taipei, Taiwan.

Email: *pychao@faculty.pccu.edu.tw

Received April $4^{\text {th }}, 2013$; revised May $4^{\text {th }}, 2013$; accepted May $11^{\text {th }}, 2013$

Copyright (C) 2013 Pi-Yu Chao et al. This is an open access article distributed under the Creative Commons Attribution License, which permits unrestricted use, distribution, and reproduction in any medium, provided the original work is properly cited.

\begin{abstract}
The aim of the study was to investigate the effect of black soybean (BS) on the susceptibility of low-density lipoprotein (LDL) in hypercholesterolemic New Zealand white rabbits. Effects of the BS extract (BSE) and its components on monocyte adhesion of human aortic endothelial cells (HAECs), and adhesion molecule were investigated. Rabbits were divided into four groups, including control, $0.5 \%$ cholesterol with $20 \%$ casein (either with or without $0.5 \%$ vitamin E), and BS groups, all fed for 8 weeks. LDL was treated with $10 \mu \mathrm{M} \mathrm{Cu}^{2+}$ in vitro to determine the LDL lag time, and the vitamin $\mathrm{E}$ content of LDL was determined. The thickness of the tunica intima was measured on paraffin sections of thoracic aortas and aortic arches stained with Movat's pentachrome. HAECs were pretreated with $100 \mu \mathrm{g} / \mathrm{ml}$ of BSE, and $10 \mu \mathrm{M}$ of genistein, daidzein, cyanidin, and aspirin for $18 \mathrm{~h}$, followed by tumor necrosis factor (TNF)- $\alpha(2 \mathrm{ng} / \mathrm{ml})$ for $6 \mathrm{~h}$, after which U937 cell adhesion was determined. Adhesion molecule expression was examined using ELISAs. The LDL lag time in the BS group was similar to that in the vitamin E group, while its lag time was significantly longer than those in the control and casein groups. The ratio of the intimal area/medial area of the aortic arch of the casein group was significantly higher than those in the control, BS, and vitamin E groups. The vitamin E group had the lowest value, and was closest to the control group. The BS group exhibited a significantly decreased atheroma region in the aortic arch compared to the casein group. Pre-incubation with BSE, genistein, daidzein, cyanidin, and aspirin significantly decreased adhesion by U937 monocytic cells to TNF- $\alpha$-stimulated HAECs. Genistein, daidzein, cyanidin, and aspirin significantly suppressed the expression of vascular cell adhesion molecule (VCAM)-1. Only genistein and aspirin significantly decreased intracellular adhesion molecule (ICAM)-1 expression compared to TNF- $\alpha$ treatment, while no treatments had any effect on E-selectin expression. BS significantly prolonged the LDL lag time and decreased the atheroma region of the aortic arch in hypercholesterolemic rabbits, thereby exerting an antiatherosclerotic effect. Presumably, the BSE downregulate intracellular redox-dependent signaling pathways in HAECs upon TNF- $\alpha$ stimulation through regulating NF- $\mathrm{kB}$, thereby attenuating the inflammatory response in atherosclerosis. The antiatherogenic and anti-inflammatory effects of BS can be used as a nutraceutical for atherogenesis prevention.
\end{abstract}

Keywords: Black Soybean; Hypercholesterolemia; Human Aortic Endothelial Cells; Adhesion

\section{Introduction}

The development of atherosclerosis is positively correlated with increasing levels of cholesterol and low-density

${ }^{*}$ Corresponding author. lipoprotein (LDL) in blood, and oxidation of LDL in vessel walls is highly related to the development of atherosclerosis $[1,2]$. Human atherosclerotic plaque contains both oxidized lipids and relatively large amounts of $\alpha$-tocopherol and ascorbate [3]. Dietary supplementation with 
$\alpha$-tocopherol increases the resistance of LDL subsequently isolated from the blood to oxidation in vitro $[4,5]$. High intake and elevated plasma levels of vitamin E are associated with low rates of ischemic heart disease in controlled intervention studies [6] and large-scale prospective studies $[7,8]$. Previous studies showed that the consumption of soy products may lower rates of cardiovascular disease, which was associated with the cholesterol-lowering action of soy and the antioxidant activity of soybean isoflavonoids [9-12]. Genistein and daidzein are the main isoflavone phytoestrogens found in soy products and a number of plants including soybeans, and have been shown to exert estrogen-like [13] and antioxidative actions [14]. High isoflavone aglycone attenuates atherosclerosis development in cholesterol-fed rabbits [15]. Esterified isoflavones can be incorporated into LDL particles, and some of them increase the in vitro oxidation resistance of LDL [16]. Esterified isoflavones contain several antioxidants, such as $\alpha$-tocopherol, ubiquinol-10, lycopene, $\beta$-carotene, and lutein [17], and may be lost during the lag phase period. In addition to the antioxidant potential, genistein prevents endothelial cells from the cytotoxic effects of oxidized (ox)-LDL [11].

Atherosclerosis is a chronic inflammatory process characterized by increased oxidative stress [18]. The resulting adhesion of monocytes to the vascular endothelium and subsequent migration into the vessel wall are pivotal early events in atherogenesis $[19,20]$. The interaction between monocytes and vascular endothelial cells may be mediated by adhesion molecules, including vascular cell adhesion molecule (CAM; VCAM)-1, intercellular adhesion molecule (ICAM)-1, and E-selectin on the surface of the vascular endothelium [21]. The inflammatory cytokine, tumor necrosis factor (TNF)- $\alpha$, activates nuclear factor $(\mathrm{NF})-\mathrm{kB}$, and activator protein (AP)-1, which are the two major redox-sensitive eukaryotic transcription factors that regulate expressions of adhesion molecules [2224]. Because activation of NF- $\mathrm{KB}$ and AP-1 can be inhibited to various degrees by different antioxidants, endogenous reactive oxygen species (ROS) may play an important role in these redox-sensitive transcription pathways in atherogenesis $[18,24]$. For example, quercetin, the most abundant flavonoid in the human diet and an excellent free radical-scavenging antioxidant, attenuates expressions of ICAM-1 and E-selectin in human aortic endothelial cells (HAECs) [25]. Several in vitro and in vivo studies showed that the cardioprotective effects of soy isoflavones include improved serum lipid profiles [26,27] and vascular reactivity [28], protection against LDL oxidation [29], modulation of cytokines, and inhibition of platelet aggregation [28]. Soy isoflavones attenuate human monocyte adhesion to endothelial cell-specific pro- tein ICAM-1 (or CD54) by inhibiting the monocyte, CD11a [30].

Black soybean (BS; Glycine max L. Merrilx), like the soybean, is a species in the genus of Glycine, but has a black testa (seed coat). BSs are abundant in natural antioxidants, such as isoflavones, saponins, anthocyanins, and vitamin E [31]. Delphinidin-3-0- $\beta$-D-glucoside from the seed coat of BS has strong antioxidant activity in an acidic environment [31]. The seed coats of 60 Chinese BS varieties contain high levels of cyanidin-3-glucoside and antioxidant activity of the oxygen radical absorbance capacity (ORAC) $[32,33]$. In addition to anthocyanins, the BS seed coat (BSSC) is also a good source of other phenolics, such as condensed tannins and phenolic acids [32, 34]. BSs abound in natural antioxidants, and their extracts prolong lag times of $\mathrm{Cu}$-induced LDL oxidation, leading to reduced atheroma formation $[35,36]$. Furthermore, Kim et al. [37] demonstrated that anthocyanins from the BSSC inhibited TNF- $\alpha$-induced ICAM- 1 and cyclooxygenase (COX)-2 levels through an NF- $\kappa \mathrm{B}-\mathrm{de}-$ pendent pathway, and had anti-inflammatory effects on an immortalized epidermal keratinocyte cell line (HaCaT).

The majority of studies showed that soybeans inhibit LDL oxidation both in vitro and ex vivo, and reduce atherosclerosis in cholesterol-fed rabbits $[12,15,38]$. The effects of BS on atherosclerosis progression of hypercholesterolemic rabbits and monocyte-endothelial cell interactions have not yet been elucidated. The objectives of our study were to determinate the effects of BS on atherosclerosis progression and ox-LDL formation in rabbits fed a cholesterol-rich diet to elucidate the mechanism by which BS alleviates atherosclerosis, and provide evidence supporting the use of antioxidants of BS in preventing atherosclerosis. The antiinflammatory effects of BSE and its components, genistein, daidzein, and cyanidin, on TNF- $\alpha$-induced cell adhesion, and adhesion molecule in an HAEC model were also investigated. The antiatherogenic and antiinflammatory effects of BS can be used as a nutraceutical for atherogenic prevention.

\section{Materials and Methods}

\subsection{Chemicals}

Medium 200, low-serum growth supplement (LSGS), fetal bovine serum (FBS), and RPMI-1640 were purchased from Gibco Invitrogen (Carlsbad, CA, USA). RayBio enzyme-linked immunosorbent assay (ELISA) kits were purchased from RayBiotech (Norcross, GA, USA). The 2,7-bis (2-carboxyethyl)-5(6)-carboxyfluo-rescein acetoxymethyl ester (BCECF-AM) was obtained from Molecular Probes (Eugene, OR, USA). Other chemical reagents were purchased from Sigma (St. Louis, MO, USA). 


\subsection{Experimental Animal Treatment}

Male New Zealand white rabbits were used in the study. The investigation conformed to the Guide for the Care of Laboratory Animals, published by the US National Institute of Health (NIH publication no. 85-23, revised 1996). All institutional and national guidelines for the care and use of laboratory animals were followed. The antiatherogenic effects of BS were evaluated using the following four rabbit groups: control, $0.5 \%$ cholesterol with $20 \%$ casein, $0.5 \%$ cholesterol with $20 \%$ casein and $0.5 \%$ vitamin E, and BS groups. Each rabbit was housed in a single cage, and fed $100 \mathrm{~g}$ daily for 8 weeks. In the week before the study began, animals were acclimatized and received a $100 \%$ standard rabbit diet. In the first and second weeks of the study period, animals received a $50 \%$ standard rabbit diet and a 50\% semi-purified diet. In the third and fourth weeks, animals received a $25 \%$ standard rabbit diet and a 75\% semi-purified diet. From the fifth study week to the end of the study period, animals received $100 \%$ semi-purified diets containing $0.5 \%$ cholesterol and individual proteins. Eight weeks after cholesterol feeding, rabbits were processed for further experiments.

\subsection{Blood Samples and Serum Cholesterol, Triglyceride, and Anthocyanin Assays}

Serum cholesterol and triglyceride levels were monitored every 2 weeks throughout the study. Thirty milliliters of blood was drawn from the ear vein of each rabbit, and was collected in sterile microcapillary glass tubes containing $1.5 \mathrm{mg} / \mathrm{ml}$ EDTA. Twenty milliliters of blood was also drawn from the heart of each rabbit. Plasma was isolated for the cholesterol, triglyceride, and anthocyanin assays. Serum was isolated for LDL determination. The cholesterol and triglyceride assays were based on the respective procedures of Allain et al. [39] and Fossati and Prencipe [40]. Two milliliters of $100 \%$ methanol containing $1 \% \mathrm{HCl}$ was used to extract anthocyanin from $0.5 \mathrm{ml}$ of plasma by centrifugation $(1500 \mathrm{~g}$ for $15 \mathrm{~min}$ at $4^{\circ} \mathrm{C}$ ) for $2 \mathrm{~h}$. The supernatant was measured using absorbances at $657\left(\mathrm{~A}_{657}\right)$ and $530 \mathrm{~nm}\left(\mathrm{~A}_{530}\right)$. Anthocyanin was calculated according to the formula: anthocyanin $($ units $/ \mathrm{ml}$ of plasma $)=\left(\mathrm{A}_{530}-\mathrm{A}_{657} \times 0.33\right) \times 2 \mathrm{ml} \times \mathrm{ml}$ of plasma [41].

\subsection{Vessel Samples}

An aortic segment was removed from the ascending arch to the diaphragm. The abdominal aorta was then taken from the diaphragm to the iliac trifurcation. Tissue samples (aortic arch and thoracic aorta) were fixed by immersion in $10 \%$ formalin fixative overnight, followed by dehydration through a graded ethanol series. Samples were then embedded in paraffin, cut into $5-\mu \mathrm{m}$ sections, and stained with Movat's pentachrome stain [42]. The severity of atherosclerosis in the arch and thoracic aorta was determined morphometrically using an LV-2 computerized image analysis system.

\subsection{LDL Isolation and Oxidative Susceptibility of the LDL Assay}

Thirty milliliters of blood was centrifuged for $10 \mathrm{~min}$ at $3000 \mathrm{rpm}$ and $4^{\circ} \mathrm{C}$. Fifteen milliliters of serum sample was collected for LDL isolation. Two steps of LDL fractionation $(1.006>\mathrm{d}>1.063 \mathrm{~g} / \mathrm{ml})$ were isolated by twostep sequential flotation ultracentrifugation [43]. A Hitachi CP85 $\beta$ ultracentrifuge (Tokyo, Japan) equipped with a $\mathrm{P} 70 \mathrm{AT}_{2}-376$ rotor at $127,980 \mathrm{~g} \mathrm{rpm}$ was used for $16 \mathrm{~h}$ $(\mathrm{d}<1.006 \mathrm{~g} / \mathrm{ml})$ to remove very LDL, and for $20 \mathrm{~h}(\mathrm{~d}<$ $1.063 \mathrm{~g} / \mathrm{ml}$ ) to collect LDL. The isolated LDL fraction from each study animal was separately dialyzed at $4^{\circ} \mathrm{C}$ against saline buffer containing $0.15 \mathrm{M} \mathrm{NaCl}$ and phosphate $(\mathrm{pH} 7.4)$ for $22 \mathrm{~h}$ before determining the oxidative susceptibility of the LDL assay. Dialyzed LDL was then diluted with saline and incubated with $10 \mu \mathrm{M}$ copper iron at a final concentration of $0.05 \mathrm{mg}$ cholesterol $/ \mathrm{ml}$. The kinetics of LDL oxidation was determined by monitoring the change in absorbance at $234 \mathrm{~nm}$ and $25^{\circ} \mathrm{C}$ with a spectrophotometer (Hitachi U-2000, Tokyo, Japan). The absorbance was recorded every 15 min for less than $5 \mathrm{~h}$. Changes in absorbance at $234 \mathrm{~nm}$ against time were divided into three consecutive phases: lag, propagation, and decomposition [44].

\subsection{Concentration of $\alpha$-Tocopherol in LDL}

The $\alpha$-tocopherol content of LDL was determined by a high-performance liquid chromatographic (HPLC) system (Merck, Darmstadt, Germany) [45]. Briefly, $1 \mathrm{ml}$ of $\alpha$-tocopherol acetate $(7.116 \mu \mathrm{g} / \mathrm{ml} \mathrm{EtOH}$ with $1 \%$ BHT, as an internal standard) was added to $0.25 \mathrm{ml}$ of LDL, followed by adding $50 \mu \mathrm{l}$ of $12 \mathrm{~N} \mathrm{HCl}$ to the samples, and extraction with $3 \mathrm{ml}$ of $\mathrm{n}$-hexane $(0.25 \%$ BHT w/w) twice. The upper hexane layer was collected and dried with nitrogen. The residue was dissolved in $200 \mu \mathrm{l}$ of methanol, followed by injection of $20 \mu \mathrm{l}$ for HPLC. The extracts were analyzed by reversed-phase HPLC (Lichropher $100 \mathrm{RP}-18,5 \mu \mathrm{m}, 125 \times 4 \mathrm{~mm}$ I.D.) eluent with methanol-water $(95: 5, \mathrm{v} / \mathrm{v})$ at a flow rate of $1.5 \mathrm{ml} / \mathrm{min}$ and a 292-nm wavelength.

\subsection{BSE Preparation}

BS seeds (Tainan no. 3 with a green cotyledon) were obtained from Dr. Tien-Joung Yiu, Tainan District Agricultural Research and Extension Station, Chiayi, Taiwan. Seeds were freeze-dried, ground, and stored at $-80^{\circ} \mathrm{C}$ un- 
til being analyzed. One gram of powdered seeds was sonicated for $20 \mathrm{~min}$ with $8 \mathrm{ml}$ of $80 \%$ methanol containing $2 \mathrm{ml}$ of $6 \mathrm{M} \mathrm{HCl}$, followed by extraction for $24 \mathrm{~h}$ at $4^{\circ} \mathrm{C}$. After centrifugation $\left(1500 \mathrm{~g}\right.$ for $10 \mathrm{~min}$ at $\left.4^{\circ} \mathrm{C}\right)$, the supernatant was collected as crude extracts containing antioxidants, and the residue was extracted again. The collected supernatant was evaporated and dissolved in $20 \mathrm{ml}$ of $80 \%$ methanol for the HPLC assay and HAEC treatment [12].

\subsection{Concentrations of Isoflavones and Cyanidin in BSs}

Daidzein and genistein in the purified mixtures were individually determined by HPLC. One milliliter of the methanolic extract of the acid hydrolysate was filtered through a $0.45-\mu \mathrm{m}$ filter prior to a $20-\mu l$ injection into a C18 reversed-phase column (Astec Silica-based, $110 \AA$, ODS, $25 \mathrm{~cm} \times 4.6 \mathrm{~mm}, 5-\mu \mathrm{m}$ particle size, Sigma-Aldrich, St. Louis, MO, USA), and eluted for $45 \mathrm{~min}$ using a ternary TSP Thermo Separation Products Pump (Agilent 1100 G1311A Quat Pump SpectraLab Scientific, Markham, Ontario, Canada). Solvents containing methanol-water (30\%:70\%; v/v) with $1 \%$ formic acid, $100 \%$ methanol, and aqueous $10 \%(\mathrm{v} / \mathrm{v})$ acetic acid were used for the HPLC. The solvent gradient was allowed to equilibrate for $15 \mathrm{~min}$ (at a flow rate of $1 \mathrm{ml} / \mathrm{min}$ ), and monitored at $528 \mathrm{~nm}$ using a Waters Photodiode Array Detector (Waters, Milford, MA, USA). Results are expressed as daidzein and genistein weight equivalents [46].

\subsection{Cell Culture and Treatment}

HAECs were grown in Medium 200 supplemented with $1 \%$ low-serum growth supplement and $10 \% \mathrm{FBS}$ in an atmosphere of $95 \%$ air and $5 \% \mathrm{CO}_{2}$ at $37^{\circ} \mathrm{C}$ in plastic flasks as described by Vielma et al. [47]. The U937 human monocytic cell line was grown in suspension culture in RPMI- 1640 containing $10 \%$ FBS and $1 \%$ of an antibiotic-antimycotic mixture. After incubation with BSE, genistein, daidzein, cyanidin, aspirin, and TNF- $\alpha$, cell viability was assessed using a 3-(4,5-dimethyl-thiazol-2yl)-2,5-diphenyl tetrazolium bromide (MTT) assay. Mitochondrial dehydrogenase activity, by the reduction of MTT in active mitochondria to purple formazan, was used to determine cell survival in a colorimetric assay. Cell viability was calculated according to the formula: Cell viability $=$ (absorbance sample tested/absorbance medium only) $\times 100 \%$.

\subsection{Cell Adhesion Assay}

To explore the effects of BSE and its components, genistein, daidzein, cyanidin, and aspirin, on endothelial cell-monocyte interactions, the adherence of U937 cells to TNF- $\alpha$-activated HAECs was examined under static conditions. HAECs were grown to confluence in 24-well plates. HAECs were then pretreated with $100 \mu \mathrm{g} / \mathrm{ml}$ of $\mathrm{BSE}$, and $10 \mu \mathrm{M}$ of genistein, daidzein, cyanidin, and aspirin for $18 \mathrm{~h}$, followed by stimulation with TNF- $\alpha$ (2 $\mathrm{ng} / \mathrm{ml}$ ) for $6 \mathrm{~h}[48,49]$. Adhesion assays of McCrohon et $a l$. [50] were performed with minor modifications. Briefly, U937 cells were labeled with $10 \mu \mathrm{mol} / 1$ of the fluorescent dye, 2,7-bis(2-carboxyethyl)-5(6)-carboxy-fluorescein acetoxymethyl ester at $37^{\circ} \mathrm{C}$ for $1 \mathrm{~h}$ in RPMI-1640 medium, and subsequently washed by centrifugation. Confluent HAECs in 24-well plates were incubated with labeled U937 cells $\left(10^{6}\right.$ cells $\left./ \mathrm{ml}\right)$ at $37^{\circ} \mathrm{C}$ for $1 \mathrm{~h}$. Nonadherent monocytes were removed, and plates were gently washed twice with PBS. Numbers of adherent monocytes were determined by counting four fields per 100fold high-power-fields using fluorescence microscopy (Nikon, Tokyo, Japan) and photographed. Four randomly chosen high-power fields were counted per well. Experiments were performed in duplicate and repeated at least 3 times independently.

\subsection{ELISA}

The effects of BSE, genistein, daidzein, cyanidin, and aspirin on the HAEC surface expressions of VCAM-1, ICAM-1, and E-selectin were analyzed with an ELISA using RayBio ELISA kits. Briefly, HAECs cultured to 95\% confluence in 24-well microplates were incubated for $18 \mathrm{~h}$ during a 6 -h TNF- $\alpha$ activation period. Monolayers were washed 3 times with cool phosphate-buffered saline (PBS), and cells were lysed with $1 \mathrm{ml}$ of Celytic reagent, vortexed, incubated on ice for $30 \mathrm{~min}$, and centrifuged at $12,000 \mathrm{~g}$ for $30 \mathrm{~min}$ at $4^{\circ} \mathrm{C}$. Aliquots $(100 \mu \mathrm{l})$ of the supernatant were frozen in liquid nitrogen, and stored at $-70^{\circ} \mathrm{C}$ until later use. The ICAM-1, VCAM-1, and E-selectin present in an aliquot were captured by an immobilized antibody after overnight incubation at $4^{\circ} \mathrm{C}$. Wells were washed 4 times with $0.1 \%$ Tween- 20 in PBS, and $100 \mu \mathrm{l}$ of 1-fold biotinylated primary antibody (specific for ICAM-1, VCAM-1, and E-selectin) was added for $1 \mathrm{~h}$ at room temperature. After washing, $100 \mu \mathrm{l}$ of HRP-conjugated streptavidin was added to the wells for $45 \mathrm{~min}$. After washing, $100 \mu \mathrm{l}$ of a 3,3',5,5'-tetramethylbenzidine substrate solution was added to the wells for $30 \mathrm{~min}$ in the dark. Finally, $50 \mu \mathrm{l}$ of $2 \mathrm{M}$ sulfuric acid was added to the cells, and the intensity of the color was measured at $450 \mathrm{~nm}$ using a spectrophotometer.

\subsection{Statistical Analysis}

Data were analyzed by a one-way analysis of variance (ANOVA), and the significance of differences between 
means was analyzed by the least significant difference (LSD) test.

\section{Results}

\subsection{Levels of Plasma Cholesterol and Triglycerides}

In the control group, the plasma cholesterol and triglyceride concentrations before the experiment were $0.72 \pm$ 0.18 and $1.60 \pm 0.33 \mathrm{~g} / \mathrm{l}$, respectively $(n=6)$ (unpublished data). Concentrations of plasma cholesterol $(0.40 \pm$ $0.06 \mathrm{~g} / \mathrm{l})$ and triglycerides $(1.64 \pm 0.10 \mathrm{~g} / \mathrm{l})$ in the control group did not change significantly during the 8 -week feeding period (Table 1). In the treatment groups, plasma cholesterol and triglyceride concentrations before the experiment in the casein $(n=6)$, BS $(n=5)$, and vitamin $\mathrm{E}(n=6)$ groups were $0.75 \pm 0.42$ and $1.72 \pm 0.16,0.77$ \pm 0.16 and $1.55 \pm 1.11$, and $0.54 \pm 0.13$ and $1.62 \pm 0.88$ $\mathrm{g} / \mathrm{l}$, respectively (unpublished data). In the treatment groups, in the 8 weeks after feeding cholesterol-containing chow to the casein, BS, and vitamin E groups, concentrations of plasma cholesterol significantly increased to $8.35 \pm 6.26,14.42 \pm 4.30$, and $10.60 \pm 2.75 \mathrm{~g} / \mathrm{l}$, respectively (Table 1). After cholesterol feeding in the casein, BS, and vitamin E groups for 8 weeks, levels of plasma triglycerides in the treatment groups were $2.27 \pm$ $0.84,2.47 \pm 1.00$, and $3.32 \pm 1.05 \mathrm{~g} / 1$, respectively (Table 1).

\subsection{BS Attenuated the Atheroma Area and Oxidative Susceptibility of LDL in New Zealand White Rabbits}

The ratio of the intimal to medial area in the aortic arch of the casein group $(0.49 \% \pm 0.29 \%)$ was significantly higher than those in the control $(0.09 \% \pm 0.02 \%)$, BS $(0.25 \% \pm 0.13 \%)$, and vitamin $\mathrm{E}$ groups $(0.05 \% \pm 0.03 \%)$ (Figure 1(a)). The atheroma region in the aortic arch of the BS group decreased $49 \%$ compared to the casein group.

Table 1. Plasma cholesterol and triglycerides of New Zealand white rabbits fed various $0.5 \%$ cholesterol-supplemented diets for 8 weeks.

\begin{tabular}{ccc}
\hline Group & Cholesterol $(\mathrm{g} / \mathrm{l})$ & Triglyceride $(\mathrm{g} / \mathrm{l})$ \\
\hline Control & $0.40 \pm 0.06^{\mathrm{c}}$ & $1.64 \pm 0.10^{\mathrm{b}}$ \\
Casein & $8.35 \pm 6.26^{\mathrm{a}, \mathrm{b}}$ & $2.27 \pm 0.84^{\mathrm{a}, \mathrm{b}}$ \\
Black soybean & $14.42 \pm 4.30^{\mathrm{a}}$ & $2.47 \pm 1.00^{\mathrm{a}, \mathrm{b}}$ \\
Casein-vit. E & $10.60 \pm 2.75^{\mathrm{a}, \mathrm{b}}$ & $3.32 \pm 1.05^{\mathrm{a}}$
\end{tabular}

All values in the experiments are presented as the mean \pm S.D. of $n=6$ (except for the black soybean group, $n=5$ ). Values with different superscripts significantly differ at $p<0.05$.
In addition, the ratio of the intimal to the medial area in the thoracic aorta of the casein group $(0.56 \% \pm 0.44 \%)$ was significantly higher than those in the control $(0.10 \%$ $\pm 0.03 \%)$, vitamin $\mathrm{E}(0.11 \% \pm 0.09 \%)$, and BS groups $(0.23 \% \pm 0.17 \%)$ (Figure 1(b)). The atheroma region of the thoracic aorta of the BS group decreased 58.9\% compared to the casein group, while atheroma formation in the thoracic aorta in the vitamin E group was prevented and was close to the control level. Figure 2 demonstrates that the lag time of LDL in the BS group $(319.6 \pm 100.5 \mathrm{~min})$ was similar to that in the vitamin $\mathrm{E}$ group $(286.7 \pm 97.0 \mathrm{~min})$, which was significantly longer than those in the control $(185.8 \pm 61.6 \mathrm{~min})$ and casein groups (187.2 $\pm 73.9 \mathrm{~min})$.

\subsection{Vitamin E Content in LDL and Anthocyanin in Plasma of New Zealand White Rabbits}

The LDL vitamin $\mathrm{E}$ content in the vitamin $\mathrm{E}$ group $(134.78 \pm 87.67 \mathrm{nmole} / \mathrm{mg}$ LDL-cholesterol) was significantly higher than those in the control $(58.77 \pm 37.72$ nmole/mg LDL-cholesterol), casein (30.23 \pm 19.07 nmole/mg LDL-cholesterol), and BS groups (57.95 \pm $68.94 \mathrm{nmole} / \mathrm{mg}$ LDL-cholesterol) (Table 2). The level of plasma anthocyanin in the BS group $(2.10 \pm 0.77$ units $/ \mathrm{ml}$ ) was significantly higher than those in the control $(0.22 \pm 0.19$ units $/ \mathrm{ml})$, casein $(0.21 \pm 0.10$ units/ $\mathrm{ml})$, and vitamin E groups $(0.29 \pm 0.08$ units $/ \mathrm{ml}$ ) (Table 2).

\subsection{Concentrations of Isoflavones and Cyanidin in the BSs}

Table 3 illustrates contents of genistein, daidzein, and cyanidin in BSs were $198.7 \pm 35.2,342.0 \pm 16.6$, and $141.5 \pm 1.8 \mu \mathrm{g} / \mathrm{g}$ of dry weight, respectively. Individual concentrations were equivalent to $0.074,0.12$, and 0.039 $\mu \mathrm{M}$ when treated with $100 \mu \mathrm{g} / \mathrm{ml} \mathrm{BSE}$ in the HAECs model (unpublished data).

Table 2. Vitamin E content in low-density lipoprotein (LDL) and anthocyanin in plasma of New Zealand white rabbits fed various $0.5 \%$ cholesterol-supplemented diets for 8 weeks.

\begin{tabular}{ccc}
\hline Group & $\begin{array}{c}\text { Vitamin E (nmole } \\
\text { /mg LDL-chol) }\end{array}$ & $\begin{array}{c}\text { Anthocyanin } \\
\text { (unit/ml) }\end{array}$ \\
\hline Control & $58.77 \pm 37.72^{\mathrm{b}}$ & $0.22 \pm 0.19^{\mathrm{b}}$ \\
Casein & $30.23 \pm 19.07^{\mathrm{b}}$ & $0.21 \pm 0.10^{\mathrm{b}}$ \\
Black soybean & $57.95 \pm 68.94^{\mathrm{b}}$ & $2.10 \pm 0.77^{\mathrm{a}}$ \\
Casein-vit. E & $134.78 \pm 87.67^{\mathrm{a}}$ & $0.29 \pm 0.08^{\mathrm{b}}$ \\
\hline
\end{tabular}

All values are presented as the mean \pm S.D. of $n=6$ (except for the black soybean group, $n=5$ ). Values with different superscripts significantly differ at $p<0.05$. 
(a)
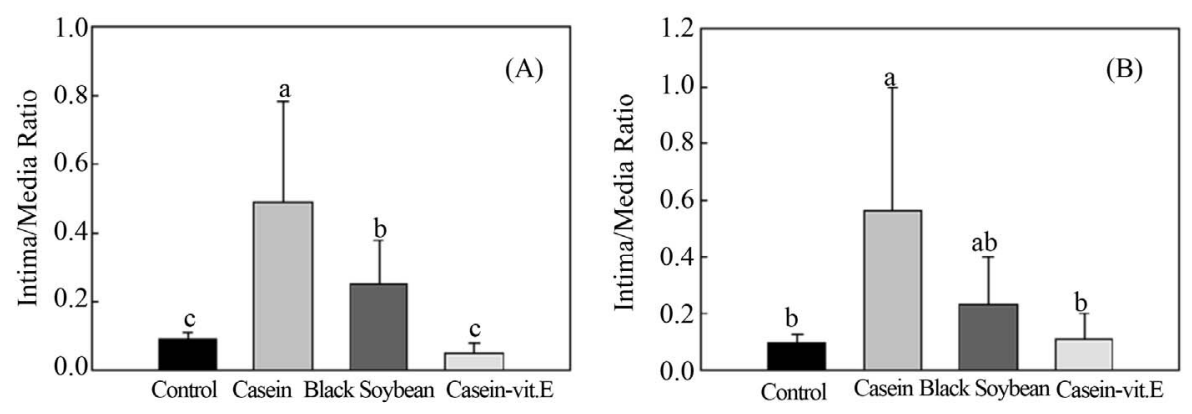

(b)
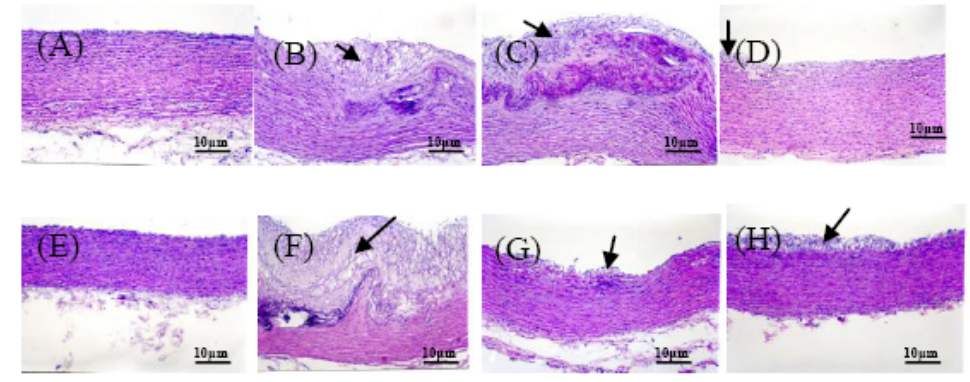

Figure 1. Effects of black soybean on aortic atherosclerosis lesions in atherosclerotic rabbits. A: Statistical data showing the atherosclerotic area ratio in the aortic arch (a) and thoracic aorta (b). All values are expressed as the mean \pm S.D. of $n=6$ (except for the black soybean group, $n=5$ ). Values with different superscript letters significantly differ from each other. B: Representative photos showing a cross-section of an atherosclerotic lesion indicative of a thickened intima. Arrows indicate the thickened intima. Images were generated using a standard light microscope at $20 \times$ magnification. Rabbits were fed one of the following diets: control diet; casein plus high-cholesterol diet; black soybean plus high-cholesterol diet; and vitamin $\mathrm{E}$ plus high-cholesterol diet. (A)-(D) Aortic arch sections were stained with H\&E. The intimal area significantly decreased in the soybean and vitamin $E$ treatment groups. (E)-(H) Thoracic aorta sections were stained with H\&E. The intimal area significantly decreased in the vitamin $E$ treatment group. Stenosis was significantly reduced in aortic arch sections of the black soybean and vitamin $\mathbf{E}$ treatment groups. Due to the death of one rabbit, there were 5 rabbits in the black soybean group, and there were 6 rabbits per group in the other three groups.

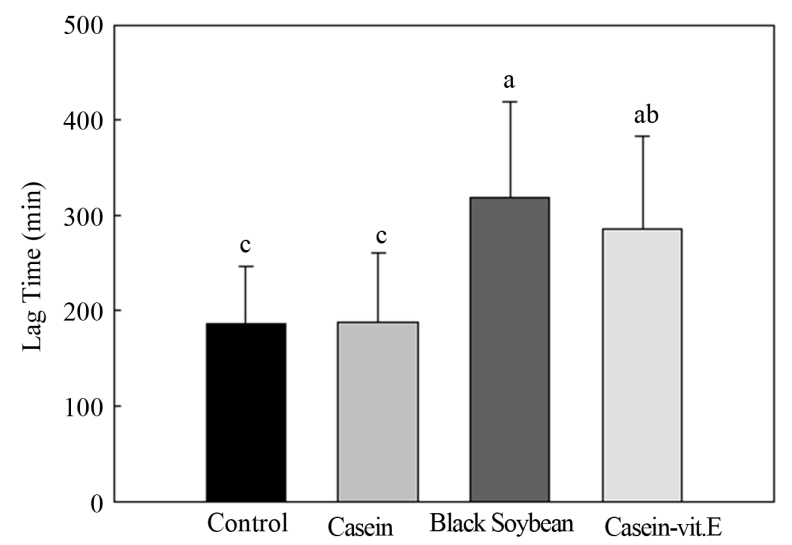

Figure 2. Effect of feeding various $0.5 \%$ cholesterol-supplemented diets for 8 weeks on the lag phase of low-density lipoprotein oxidation in New Zealand white rabbits.

\subsection{Effects of BSE and its Components on Cell Viability}

The effects of BSE and its components on cell cytoto-
Table 3. Contents of the main compounds of black soybean from the crude methanolic extract.

\begin{tabular}{cc}
\hline Compounds & Contents $\left(\mu \mathrm{g} / \mathrm{g}\right.$ of DW extract) ${ }^{\mathrm{a}}$ \\
\hline Genistein & $198.7 \pm 35.2$ \\
Daidzein & $342.0 \pm 16.6$ \\
Cyanidin & $141.5 \pm 1.8$ \\
\hline
\end{tabular}

${ }^{\mathrm{a}}$ Values are the mean of three triplicate determinations.

xicity were determined by an MTT assay. HAECs were incubated with BSE (50 - $200 \mu \mathrm{g} / \mathrm{ml})$ and its components $(5-40 \mu \mathrm{M})$ for $18 \mathrm{~h}$ at various concentrations. Cyanidin at a concentration of $>20 \mu \mathrm{M}$ showed damage to the viability of HAECs, but none of the other treatments had significant effects on the viability of cells, which had cell viabilities of $>90 \%$ (unpublished data). Therefore, concentrations of $10 \mu \mathrm{M}$ of genistein, daidzein, cyanidin and $100 \mu \mathrm{g} / \mathrm{ml}$ of the BSE were chosen for the study. 


\subsection{BSE and its Components Reduced TNF- $\alpha$-Induced Adhesion of Monocytes to HAECS}

To determine the effect of BSE and its components on the adhesion of U937 cells to endothelial cells, HAECs were pretreated with $100 \mu \mathrm{g} / \mathrm{ml}$ of BSE and $10 \mu \mathrm{M}$ of genistein, daidzein, cyanidin, and aspirin for $18 \mathrm{~h}$, followed by stimulation with TNF- $\alpha(2 \mathrm{ng} / \mathrm{l})$ for $6 \mathrm{~h}$. Fluorescence-labeled monocytic U937 cells were added to HAECs and allowed to adhere for $2 \mathrm{~h}$. The percentage cell adhesion was evaluated by quantification with the BCECF-AM staining method. However, BSE and its components (independently used to treat HAECs) did not adhere to U937 cells. Adhesion of U937 cells to TNF- $\alpha$ was stimulated in HAECs which increased by about 14fold higher than that of the control group (Figure 3). Adhesion was markedly decreased by treatment with BSE and its components, which showed significantly decreased adhesion of U937 monocytic cells to TNF- $\alpha$-stimulated HAECs by $98.2 \%$ with BS, $97.2 \%$ with genistein, $98.8 \%$ with daidzein, $93.1 \%$ with cyanidin, and $90.9 \%$ with aspirin (Figure 3). An examination of the cytotoxicity of BSE and its components on endothelial cells using an MTT assay indicated that BSE and its components had no adverse effect on cell viability $(>90 \%$ cell viability, unpublished data). Therefore, the inhibition of monocyte adhesion to endothelial cells in the presence of BSE and its components was not the result of cytotoxicity.

\subsection{BSE and Its Components Attenuated TNF- $\alpha$-Induced CAM Protein Expression}

Because the expression of CAMs by endothelial cells is a prerequisite for adhesion of monocytes, effects of $\mathrm{BS}$ on TNF- $\alpha$-induced expressions of ICAM-1, VCAM-1, and E-selectin were investigated. Results from Figures 4-6 demonstrate that ICAM-1, VCAM-1, and E-selectin were expressed at low levels on unstimulated endothelial cells. There was $>2$-fold increases in the expressions upon stimulation with TNF- $\alpha$ in VCAM-1. Pretreatment of endothelial cells with BS, genistein, daidzein, cyanidin, and aspirin significantly inhibited TNF- $\alpha$-induced VCAM-1 expression levels by $47 \%, 56.8 \%, 59 \%, 38.9 \%$, and $42.7 \%$, respectively (Figure 4). Moreover, genistein, daidzein and aspirin significantly decreased ICAM-1 expression by $33.4 \%, 17.1 \%$ and $41.7 \%$, respectively (Figure 5), while no treatments had any effect on E-selectin (Figure 6).

\section{Discussion}

\subsection{BS Alleviated Atheroma and Ox-LDL Formation through Its Antioxidative Efficacy of Isoflavones, Vitamin E, and Anthocyanins}

The underlying mechanism of the protective effect of BS (a)
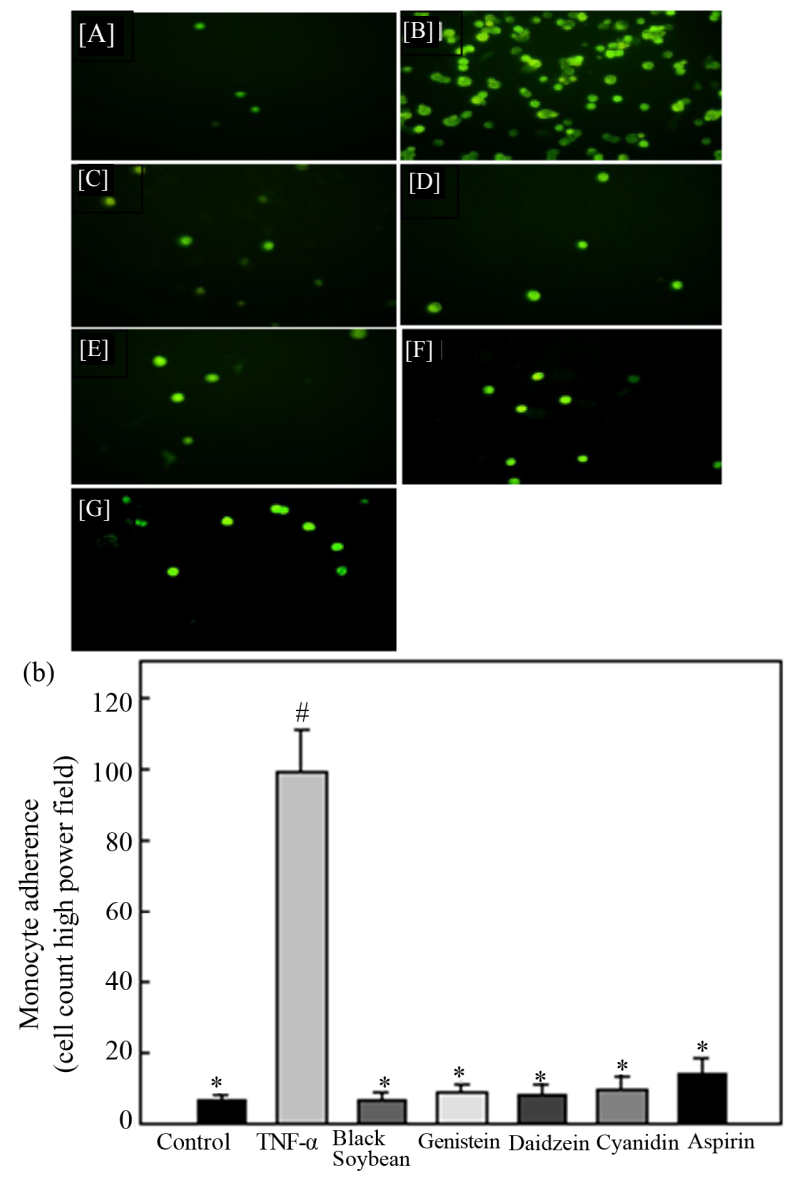

Figure 3. Black soybean extract and its components reduce tumor necrosis factor (TNF)- $\alpha$-induced adhesion of monocytes to human aortic endothelial cells (HAECs). (a) The number of adherent $\mathrm{U} 937$ cells was monitored by fluorescence microscopy. [A] Control; [B] TNF- $\alpha$ (2 ng/ml); [C] co-treated with TNF- $\alpha$ and black soybean extract (100 $\mu \mathrm{g} / \mathrm{ml})$; $[\mathrm{D}]$ co-treated with TNF- $\alpha$ and genistein $(10 \mu \mathrm{M})$; [E] co-treated with TNF- $\alpha$ and daidzein $(10 \mu \mathrm{M})$; $[\mathrm{F}]$ cotreated with TNF- $\alpha$ and cyanidin $(10 \mu \mathrm{M}) ;[\mathrm{G}]$ co-treated with TNF- $a$ and aspirin $(10 \mu M)$. (b) HAECs were pretreated with black soybean extract and its components for $18 \mathrm{~h}$, and then stimulated with TNF- $\alpha$ for $6 \mathrm{~h}$. Fluorescence-labeled monocytic U937 cells were added to HAECs, and allowed to adhere for $2 \mathrm{~h}$. Adherent cells were measured as described in "Materials and methods". Data are expressed as a percentage of TNF- $\alpha$-induced expression (mean \pm S.D.) of three experiments. \# $p<0.01$ vs. the control, ${ }^{*} p<0.05$ vs. TNF- $\alpha$ alone.

on the development of atherosclerosis was investigated in the present study. It was proposed that hyperlipidemia is a well-established risk factor for atherosclerosis, and drugs with a hypolipidemic effect are used clinically to inhibit atherosclerosis formation and progression [51]. Thus, the effect of BS on serum lipid profiles of rabbits was observed in this study. Results from Table 1 show 


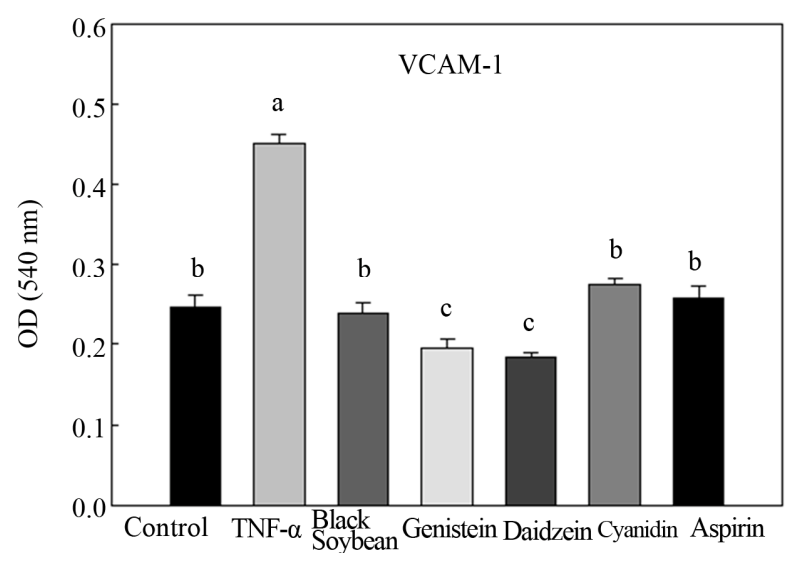

Figure 4. Effect of black soybean extract and its components on human aortic endothelial cell (HAEC) expression of vascular cell adhesion molecule (VCAM)-1. Data are presented as the mean \pm S.D. of three experiments, ${ }^{\mathrm{a}-\mathrm{c}} p<0.05$.

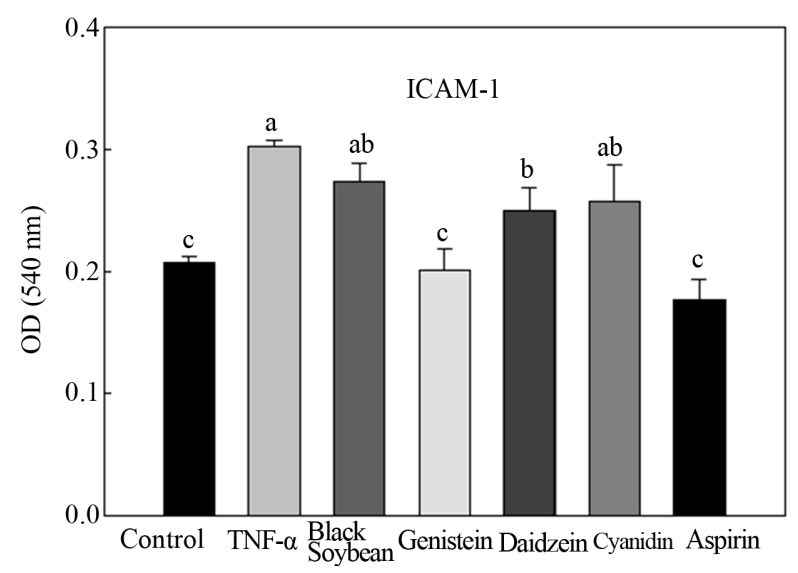

Figure 5. Effects of black soybean extract and its components on human aortic endothelial cell (HAEC) expression of intercellular adhesion molecule (ICAM)-1. Data are presented as the mean \pm S.D. of three experiments, ${ }^{\mathrm{a}-\mathrm{c}} p<0.05$.

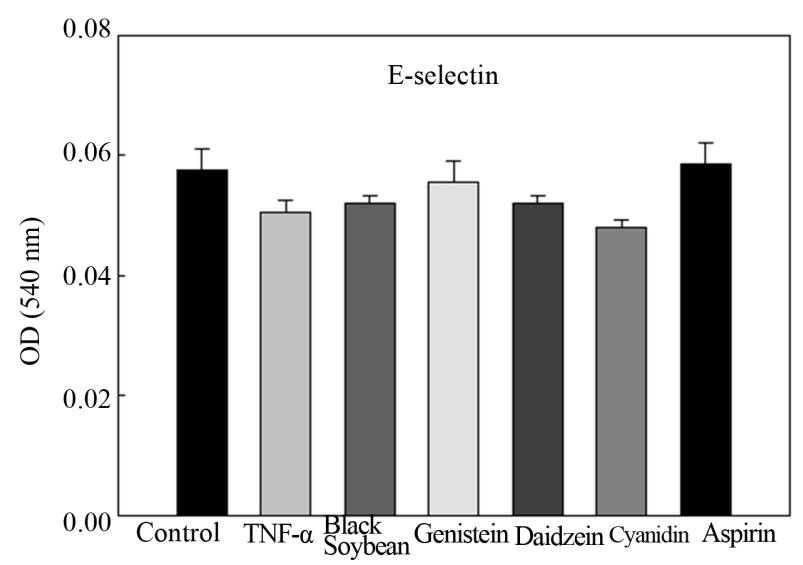

Figure 6. Effects of black soybean extract and its components on human aortic endothelial cell (HAEC) expression of E-selectin. Data are presented as the mean \pm S.D. of three experiments. that BS had no influence on the serum lipid profiles compared to the cholesterol-fed casein group, suggesting that actions other than the lipid-lowering effect of BS were responsible for the amelioration of atherosclerosis in rabbits. In addition, vitamin $\mathrm{E}$ inhibited atherosclerosis, which perhaps was through a significant reduction in the LDL oxidization ability. BS significantly decreased atherosclerotic plaque formation only in the aortic arch region, and tended to reduce atherosclerotic plaque formation in the thoracic aorta region, although it significantly reduced the LDL oxidization ability. In other studies, soy protein significantly decreased atherosclerosis at the aortic arch and thoracic aorta of rabbits, and soy protein isolate affected both the prevalence of atherosclerosis and the plaque size [10]. The alcohol extract of soy protein significantly lowered LDL cholesterol concentrations [52]. Both high (1\%) and low (0.33\%) isoflavone aglycone extracts without soy protein significantly decreased aortic arch lesions by $36.9 \%$ and $26.3 \%$, respectively, and reduced cholesteryl ester hydroperoxide levels in LDL and the aortic arch [15]. In our study, BS significantly decreased the aortic arch lesion by $49 \%$, which was better than the high (1\%) isoflavone aglycone group. The thoracic aorta lesion in the BS group decreased 58.9\%, similar to $1 \%$ isoflavone aglycones which reduced the thoracic aorta lesion in cholesterol-fed rabbits by $57.3 \%$ [15]. Antioxidative actions of isoflavones inhibit the oxidation of LDL, thereby exerting an antiatherosclerotic effect.

$\alpha$-Tocopherol administration in rabbits may have directly diminished lesion formation by preventing radicalmediated injury and inflammatory reactions in the endothelium and aortic intima. This possibility is consistent with a report which showed that vitamin E directly diminished U-937 monocyte adhesion to inflammatory cytokine-stimulated endothelial cells in tissue culture [53]. $\alpha$ Tocopherol as the sole lipophilic antioxidant in moderately hypercholesterolemic hamsters substantially suppressed vascular oxidative stress and atherogenesis [54]. The vitamin E group in our study also demonstrated inhibition of LDL oxidation and suppression of aortic lesion formation (Figures 1 and 2).

The isoflavone aglycones, genistein, and daidzein, have scavenging activities [55] and antioxidant properties [55, 56]. Isoflavone phytoestrogens act as antioxidants, providing increased oxidation resistance for lipoproteins [12]. However, due to their relative hydrophilicity, these isoflavones are incorporated into LDL to only a small extent, corresponding to approximately one isoflavone molecule for each 500 LDL molecules $(\leq 0.33$ molecules/LDL particle), and the oxidation resistance of particles showed no change. Genistein and daidzein were then converted into fat-soluble derivatives by esterification with fatty acids to facilitate their incorporation into LDL. Oleic acid esters 
were incorporated most effectively, reaching a concentration of 2.19 molecules per LDL particle, and resulting in significantly increased oxidation resistance in vitro [16]. Isoflavones may protect lipoproteins against oxidation, because they are converted to lipophilic derivatives and incorporated into lipoprotein particles [57].

Consumption of antioxidant flavonoids in tea, fruits, and vegetables, lycopene in tomato products, and vitamin $\mathrm{E}$ as a supplement is associated with a reduced risk of coronary heart disease $[58,59]$. Both vitamin $\mathrm{E}$ and black tea significantly increased the lag phase of hyper-cholesterolemic rabbits; however, neither treatment had any effect on the formation of atherosclerotic lesions [60]. The lag phase had no significant association with the extent of atherosclerosis. Yang et al. [61] reported that salvianolic acid (Sal B), a water-soluble antioxidant obtained from a Chinese medicinal herb, reduced $\mathrm{Cu}^{2+}$-induced LDL oxidation, lipid deposition in the thoracic aorta, intimal thickness of the aortic arch and thoracic aorta, and neointimal formation in the abdominal aorta. In our study, the content of anthocyanin in BS was $119.63 \pm$ 0.79 units/g (unpublished data), while the level of anthocyanin in plasma was $2.1 \pm 0.77$ units $/ \mathrm{mL}$ (Table 2). BS had a high level of cyanidin-3-O-glucoside, which may account for part of its antioxidative capacity [12]. Yoshikurk and Hamaguchi [62] identified delphinidin 3-glucoside and cyanidin 3-glucoside as two anthocyanins in the black-seeded variety of soybean. Zhang et al. [33] further identified six anthocyanins, including delphinidin-3-glucoside, cyanidin-3-galactoside, cyanidin-3-glucoside, petunidin-3-glucoside, peonidin-3-glu-coside, and malvidin3 -glucoside in 60 varieties of Chinese BSSCs, which contained significantly more cyanidin-3-glucoside in the range of $61.8-1617.4 \mathrm{mg} / 100 \mathrm{~g}$, and had a distribution of $48.8 \%-94.1 \%$ of the total anthocyanin content. This may explain some of the BS results regarding the prolonged lag phase and the reduction in the atheroma region of the aortic arch. Furthermore, respective contents of genistein and daidzein in BS were $198.7 \pm 35.2$ and $342.0 \pm 16.6 \mu \mathrm{g} / \mathrm{g}$ dry weight, respectively (Table 3), while the vitamin E content was $20.63 \pm 0.63 \mu \mathrm{g} / \mathrm{g}$ (data not presented). Contents of genistein, daidzein, vitamin E, and anthocyanins in BS may play synergistic roles in the antioxidative efficacy. Considering that BS was shown to inhibit the in vitro oxidation of LDL $[35,36]$, it is reasonable to deduce that the antiatherosclerotic effect of BS in this study might have been derived from its antioxidant activity. The present study demonstrates that attenuation of oxidative stress by BS, resulting from the enhanced antioxidant effect in both the serum and aorta, might be one of the mechanisms contributing to the amelioration of atherosclerosis in hyperlipidemic rabbits. BS alleviates atherosclerosis, and it provides evidence to support the use of antioxidants to prevent atherosclerosis.

\subsection{BSE and Its Components Block Adhesion Molecule-Endothelial Cell Interactions}

Adhesion of monocytes to the vascular endothelium and subsequent migration into the vessel wall are early events in atherogenesis [20]. Proinflammatory cytokines, including TNF- $\alpha$, interferon (IFN)- $\gamma$, IL-1, IL-8, monocyte chemoattractant protein (MCP)-1, macrophage colony-stimulating factor (M-CSF), cyclooxygenase (COX)-2, nitric oxide synthase (NOS), and CD40, enhanced expressions of surface expression adhesion molecules, such as ICAM-1, VCAM-1, and E-selectin [63,64]. Dietary polyphenols, such as catechin and quercetin, significantly reduce binding of monocytes to HAECs $[65,66]$, which is similar to the results of the present study. Figures 4 and 5 illustrate that the reduced cellular adhesion may have been due to inhibition of CAM expression as genistein and daidzein reduced both VCAM-1 and ICAM-1 expressions, and BSE and cyanidin only reduced VCAM-1 expression. Genistein significantly inhibited IL-1- and TNF- $\alpha$-induced upregulation of neutrophils and monocyte adherence [67]. Induction of ICAM-1, VCAM-1, and E-selectin surface expressions by TNF was reduced by the protein tyrosine kinase inhibitor, genistein, suggesting that specific phosphorylation following protein tyrosine kinase activation may be required for NF- $\mathrm{\kappa B}$ mobilization and induction of VCAM-1 and endothelial leukocyte adhesion molecule 1 (ELAM-1) by TNF [68]. Similar results were also observed in different studies $[69,70]$. These findings reveal that tyrosine-phosphorylated proteins may regulate leukocyte adherence and CAM expression in the endothelium [71]. Recently, Chinta et al. [72] demonstrated that daidzein significantly suppressed the production of the proinflammatory factors, nitric oxide and interleukin 6 (IL-6), and reduced ROS production, p38 MAPK phosphorylation, and NF- $\mathrm{KB}$ activation. Endothelial cells treated with the soy isoflavone, genistein, inhibited monocyte adhesion, suggesting that the atheroprotective effect of soy isoflavones can be mediated by regulating endothelial cell functions [73]. In addition, modulation of interactions between inflammatory factors, such as IL-6 and endothelial cells may be a plausible mechanism explaining the beneficial effects of soy-based diets. Nagarajan et al. [30] also showed that pre-exposure to soy isoflavones inhibited monocyte adhesion to endothelial cells through the endothelial ICAM (CD54). This inhibition by isoflavones led to less production of inflammatory cytokines, such as IL-6 and IL-8, by monocytes. The mechanism by which soy isoflavones block monocyte adhesion was through inhibition of CD11a (integrins) affinity to CD54.

Many groups have identified a number of small mo- 
lecules from natural sources and several plant extracts that block nuclear accumulation of NF- $\mathrm{KB}$ and abrogate TNF- $\alpha$-induced expressions of ICAM-1, VCAM-1, and E-selectin by endothelial cells $[74,75]$. In addition, several reports showed that natural products with antioxidant activity inhibit the TNF- $\alpha$-induced activation of redox-sensitive NF- $\mathrm{KB}$ [76-78]. Kim et al. [34] reported that anthocyanidin reduced ICAM-1 and VCAM-1 expressions through inhibiting the nuclear translocation of NF-кB. Furthermore, Kim et al. [37] demonstrated that anthocyanins from BSSC inhibited TNF- $\alpha$-induced ICAM1 and COX-2 levels through an NF- $\mathrm{kB}-$ dependent pathway, and had anti-inflammatory effects on the $\mathrm{HaCaT}$ cell line. It is possible that cyanidin and isoflavones influenced inhibitory proteins of nuclear factor- $\mathrm{KB} \alpha(\mathrm{I} \kappa \mathrm{B} \alpha)$ and of IкB kinase $\alpha$ (IKK $\alpha$ ) activity as suggested by Garciau-Mediavilla et al. [79] and Min et al. [80].

\section{Conclusion}

BS had no effect on serum lipid profiles. Suppression of LDL oxidation by BS was through attenuation of oxidative stress, which contributes, at least in part, to the amelioration of atherosclerosis. Presumably, the atheroprotective effect of BS diets is mediated by blocking adhesion molecular-endothelial cell interactions through an

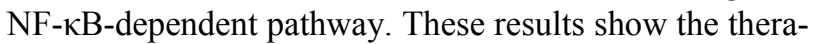
peutic potential of BS as an atheroprotective and antiinflammatory agent for the use in cytokine-induced vascular disorders, including atherosclerosis.

\section{Acknowledgements}

This research was supported by a grant from the National Science Council of Taiwan (NSC87-2313-B-034-004). We express our appreciation to Mr. Hsuan-Hui Chang for his assistance with lab work.

\section{REFERENCES}

[1] D. Steinberg, "Lipoproteins and Atherogenesis," Journal of the American Medical Association, Vol. 264, No. 23, 1990, pp. 3047-3052. doi:10.1001/jama.1990.03450230083034

[2] J. L. Witzum and D. Steinberg, "Role of Oxidized Low Density Lipoprotein in Atherogensis," Journal of Clinical Investigation, Vol. 88, No. 6, 1991, pp. 1785-1792. doi:10.1172/JCI115499

[3] C. Suarna, R. T. Dean, J. May and R. Stocker, "Humann Atherosclerotic Plaque Contains Both Oxidized Lipid and Relatively Large Amounts of $\alpha$-Tocopherpl and Ascorbate," Arteriosclerosis, Thrombosis, and Vascular Biolo$g y$, Vol. 15, No. 10, 1995, pp. 1616-1624. doi:10.1161/01.ATV.15.10.1616

[4] D. Steinberg, "Antioxidants and Atherosclerosis," Circulation, Vol. 84, No. 3, 1991, pp. 1420-1425.

\section{doi:10.1161/01.CIR.84.3.1420}

[5] I. Jialal and S. M. Grundy, "Effect of Combined Supplementation with $\alpha$-Tocopherol, Ascorbate and $\beta$-Carotene on Low Density Lipoprotein Oxidation," Circulation, Vol. 88 , No. 6, 1993, pp. $2780-2786$.

doi:10.1161/01.CIR.88.6.2780

[6] N. G. Stephens, A. Parsons, P. M. Schofield, F. Kelly, K. Cheeseman, M. J. Mitchinson and M. J. Brown, "Randomised Controlled Trial of Vitamin E in Patients with Coronary Disease: Cambridge Heart Antioxidant Study (CHAOS)," Lancet, Vol. 347, No. 9004, 1996, pp. 781786. doi:10.1016/S0140-6736(96)90866-1

[7] E. B. Rimm, M. J. Stampfer, A. Ascherio, E. Giovannucci, G. A. Colditz and N. Willeet, "Vitamin E Consumption and the Risk of Coronary Heart Disease in Men," New England Journal of Medicine, Vol. 328, No. 20, 1993, pp. 1450-1456. doi:10.1056/NEJM199305203282004

[8] M. J. Stampfer, C. H. Henneknes, J. E. Manson, G. A. Colditz, B. Rosner and W. C. Willett, "Vitamin E Consumption and the Risk of Coronary Disease in Women," New England Journal of Medicine, Vol. 328, No. 20, 1993, pp. 1444-1449. doi:10.1056/NEJM199305203282003

[9] J. W. Anderson, B. M. Johnstone and M. E. Cook-Newell, "Meta-Analysis of the Effects of Soy Protein Intake on Serum Lipids," New England Journal of Medicine, Vol. 333, 1995, pp. 276-282. doi:10.1056/NEJM199508033330502

[10] M. S. Anthony, T. B. Clarkson, B. C. Bullock and J. D. Wagner, "Soy Protein versus Soy Phytoestrogens in the Prevention of Diet-Induced Coronary Artery Atherosclerosis of Male Cynomolgus Monkeys," Arteriosclerosis, Thrombosis, and Vascular Biology, Vol. 17, 1997, pp. 2524-2531. doi:10.1161/01.ATV.17.11.2524

[11] S. Kspiotis, M. Hermann, I. Held, C. Seelos, H. Ehringer and B. M. K. Gmeiner, "Genistein, the Dietary-Derived Angiogenesis Inhibitor, Prevents LDL Oxidation and Protects Endothelial Cells from Damage by Atherogenic LDL," Arteriosclerosis, Thrombosis, and Vascular Biology, Vol. 17, No. 11, 1997, pp. 2868-2874. doi:10.1161/01.ATV.17.11.2868

[12] R. Takahashi, R. Ohmori, C. Kiyose, Y. Momiyama, F. Ohsuzu and K. Kondo, "Antioxidant Activities of Black and Yellow Soybeans against Low Density Lipoprotein Oxidation," Journal of Agricultural and Food Chemistry, Vol. 53, No. 11, 2005, pp. 4578-4582. doi: $10.1021 / \mathrm{jf} 048062 \mathrm{~m}$

[13] G. G. Kuiper, J. G. Lemmen, B. Carlsson, J. C. Corton, S. H. Safe, P. T. van der Saag, B. van der Burg and J. A. Gustafsson, "Interaction of Estrogenic Chemicals and Phytoestrogens with Estrogen Receptor Beta," Endocrinology, Vol. 139, No. 10, 1998, pp. 4252-4263. doi:10.1210/en.139.10.4252

[14] R. C. Siow, F. Y. Li, D. J. Rowlands, P. de Winter and G. E. Mann, "Cardiovascular Targets for Estrogens and Phytoestrogens: Transcriptional Regulation of Nitric Oxide Synthase and Antioxidant Defense Genes," Free Radical Biology and Medicine, Vol. 42, No. 7, 2007, pp. 909-925. 


\section{doi:10.1016/j.freeradbiomed.2007.01.004}

[15] J. Yamakoshi, M. K. Piskula, T. Izumi, K. Tobe, M. Saito, S. Kataoka, A. Obata and M. Kikuchi, "Isoflavone Aglycone-Rich Extract without Soy Protein Attenuates Atherosclerosis Development in Cholesterol-Fed Rabbits," Journal of Nutrition, Vol. 130, No. 8, 2000, pp. 18871893.

[16] Q. H. Meng, P. Lewis, K. Wahala, H. Aadlercreutz and M. J. Tikkanen, "Incorporation of Esterified Soybean Isoflavones with Antioxidant Activity into Low Density Lipoprotein," Biochimica et Biophysica Acta, Vol. 1438, No. 3, 1999, pp. 369-376. doi:10.1016/S1388-1981(99)00062-1

[17] H. Esterbauer, J. Gebicki, H. Puhl and G. Jurgens, "The Role of Lipid Peroxidation and Antioxidants in Oxidative Modification of LDL," Free Radical Biology and Medicine, Vol. 13, No. 4, 1992, pp. 341-390. doi:10.1016/0891-5849(92)90181-F

[18] W. Palinski, "Conjunct Regulation of Aortic Antioxidant Enzymes during Atherogenesis," Circulation Research, Vol. 93, No. 3, 2003, pp. 183-185. doi:10.1161/01.RES.0000087332.75244.42

[19] R. Ross, "The Pathogenesis of Atherosclerosis: A Perspective for the 1990s," Nature, Vol. 362, No. 6423, 1993, pp. 801-809. doi:10.1038/362801a0

[20] P. Libby, "Molecular Basis of the Acute Coronary Syndromes," Circulation, Vol. 91, 1995, pp. 2844-2850. doi:10.1161/01.CIR.91.11.2844

[21] Cybulsky M. I. and M. A. Gimbrone, "Endothelial Expression of a Mononuclear Leukocyte Adhesion Molecule during Atherogenesis," Science, Vol. 251, No. 4995, 1991, pp. 788-791. doi:10.1126/science. 1990440

[22] P. A. Baeuerle and D. Baltimore, "NF-kappa B: Ten Years after," Cell, Vol. 87, No. 1, 1996, pp. 13-20. doi:10.1016/S0092-8674(00)81318-5

[23] J. A. DiDonato, M. Hayakawa, D. M. Rothwarf, E. Zandi and M. Karin, "A Cytokine-Responsive IkappaB Kinase that Activates the Transcription Factor NF-kappa B," Nature, Vol. 388, 1997, pp. 548-554. doi:10.1038/41493

[24] J. M. Muller, R. A. Rupec and P. A. Baeuerle, "Study of Gene Regulation by NF-Kappa B and AP-1 in Response to Reactive Oxygen Intermediates," Methods, Vol. 11, No. 3, 1997, pp. 301-312. doi:10.1006/meth.1996.0424

[25] S. B. Lotito and F. Balz, "Dietary Flavonoids Attenuate Tumor Necrosis Factor- $\alpha$ Induced Adhesion Molecule Expression in Human Aortic Endothelial Cells," Journal of Biological Chemistry, Vol. 281, No. 48, 2006, pp. 3710237110. doi:10.1074/jbc.M606804200

[26] A. A. Ali, M. T. Velasquez, C. T. Hansen, A. I. Mohamed and S. J. Bhathena, "Effects of Soybean Isoflavones, Probiotics, and Their Interactions on Lipid Metabolism and Endocrine System in an Animal Model of Obesity and Diabetes," Journal of Nutritional Biochemistry, Vol. 15, No. 10, 2004, pp. 583-590. doi:10.1016/j.jnutbio.2004.04.005

[27] B. L. McVeigh, B. L. Dillingham, J. W. Lampe and A. M. Duncan, "Effect of soy Protein Varying in Isoflavone Content on Serum Lipids in Healthy Young Men," American
Journal of Clinical Nutrition, Vol. 83, No. 2, 2006, pp. 244-251.

[28] G. Rimbach, C. Boesch-Saadatmandi, J. Frank, D. Fuchs, U. Wenzel, H. Daniel, W. L. Hall and P. D. Weinberg, "Dietary Isoflavones in the Prevention of Cardiovascular Disease A Molecular Perspective," Food and Chemical Toxicology, Vol. 46, No. 4, 2008, pp. 1308-1319. doi:10.1016/j.fct.2007.06.029

[29] N. R. T. Damasceno, E. Apolinário, F. D. Flauzino, I. Fernandes and D. S. P. Abdalla, "Soy Isoflavones Reduce Electronegative Low-Density Lipoprotein (LDL-) and Anti-LDL-Autoantibodies in Experimental Atherosclerosis," European Journal of Nutrition, Vol. 46, No. 3, 2007, pp. 125-132. doi:10.1007/s00394-006-0640-9

[30] S. Nagarajan, B. W. Stewart and T. M. Badger, "Soy Isoflavones Attenuate Human Monocyte Adhesion to Endothelial Cell-Specific CD54 by Inhibiting Monocyte CD11a," Journal of Nutrition, Vol. 136, No. 9, 2006, pp. 2384-2390.

[31] T. Tsuda, K. Ohshima, S. Kawakishi and T. Osawa, "Antioxidative Pigments Isolated from the Seeds of Phaseolus vulgaris L," Journal of Agricultural and Food Chemistry, Vol. 42, No. 2, 1994, pp. 248-251. doi:10.1021/jf00038a004

[32] B. J. Xu and S. K. C. Chang, "Antioxidant Capacity of Seed Coat, Dehulled Bean, and Whole Black Soybeans in Relation to Their Distributions of Total Phenolics, Phenolic Acids, Anthocyanins, and Isoflavones," Journal of Agricultural and Food Chemistry, Vol. 56, No. 18, 2008, pp. 8365-8373. doi:10.1021/jf801196d

[33] R. F. Zhang, F. X. Zhang, M. W. Zhang, Z. C. Wei, C. Y. Yang, Y. Zhang, X. J. Tang, Y. Y. Deng and J. W. Chi, "Phenolic Composition and Antioxidant Activity in Seed Coats of 60 Chinese Black Soybean (Glycine max L. Merr.) Varieties," Journal of Agricultural and Food Chemistry, Vol. 59, No. 11, 2011, pp. 5935-5944. doi:10.1021/jf201593n

[34] H. J. Kim, I. Tsoy, J. M. Park, J. I. Chung, S. C. Shin and K. C. Chang, "Anthocyanins from Soybean Seed Coat Inhibit the Expression of TNF-a-Induced Genes Associated with Ischemia/Reperfusion in Endothelial Cell by NF- $\kappa B-$ Dependent Pathway and Reduce Rat myocardial Damages Incurred by Ischemia and Reperfusion in Vivo," FEBS Letters, Vol. 580, No. 5, 2006, pp. 1391-1397. doi:10.1016/j.febslet.2006.01.062

[35] B. J. Xu, S. H. Yuan and S. K. C. Chang, "Comparative Studies on the Antioxidant Activities of Nine Common Food Legumes against Copper-Induced Human Low-Density Lipoprotein Oxidation in Vitro," Journal of Food Science, Vol. 72, No. 7, 2007, pp. S522-S527. doi:10.1111/j.1750-3841.2007.00464.x

[36] Y. F. Chen, S. L. Lee and C. C. Chou, "Fermentation with Aspergillus awamori Enhanced Contents of Amino Nitrogen and Total Phenolics as Well as the Low-Density Lipoprotein Oxidation Inhibitory Activity of Black Soybeans," Journal of Agricultural and Food Chemistry, Vol. 59, No. 8, 2011, pp. 3974-3979. doi:10.1021/jf2001684

[37] H. J. Kim, L. Xu, K. C. Chang, S. C. Shin, J. I. Chung, D. 
Kang, S. H. Kim, J. A. Hur, T. H. Choi, S. Kim and J. Choi, "Anti-Inflammatory Effects of Anthocyanins from Black Soybean Seed Coat on the Keratinocytes and Ischemia-Reperfusion Injury in Rat Skin Flaps," Microsurgery, Vol. 32, No. 7, 2012, pp. 1-8. doi:10.1002/micr.22019

[38] M. J. Tikkanen, K. Wahala, S. Ojala, V. Vihma and H. Adercreutz, "Effect of Soybean Phytoestrogen Intake on Low Density Lipoprotein Oxidation Resistance," Proceedings of the National Academy of Sciences of the United States of America, Vol. 95, No. 6, 1998, pp. 31063110. doi:10.1073/pnas.95.6.3106

[39] C. C. Allain, L. S. Poon, C. S. G. Chan, W. Richmond and P. C. Fu, "Enzymatic Determination of Total Serum Cholesterol," Clinical Chemistry, Vol. 20, No. 4, 1974, pp. 470-475.

[40] P. Fossati and L. Prencipe, "Serum Triglyceride Determined Colorimetrically with an Enzyme That Produces Hydrogen Peroxide," Clinical Chemistry, Vol. 28, No. 10, 1982, pp. 2077-2080.

[41] A. L. Mancinelli, C. P. Huang Yang, P. Lindquist, O. R. Anderson and I. Rabino, "Photocontrol of Anthocyanin Synthesis III. The Action of Streptomycin on the Synthesis of Chlorophyll and Anthocyanin," Plant Physiology, Vol. 55, No. 2, 1975, pp. 251-257.

[42] D. C. Sheehan and B. B. Hrapahak, "Theory and Practice of Histochnology," 2nd Edition, Battelle Press, Columbus, 1987.

[43] V. N. Schumasker and D. L. Puppione, "Sequential Flotation Ultracentrifugation," Methods in Enzymology, Vol. 128, 1986, pp. 155-170. doi:10.1016/0076-6879(86)28066-0

[44] H. A. Kleeinveld, H. L. M. Hak-Lemmers, A. F. H. Stalenhoef and P. N. M. Demacker, "Improved Measurement of Low Density Lipoprotein Susceptibility to CopperInduced Oxidation: Application of a Short Procedure for Isolating Low-Density Lipoprotein," Clinical Chemistry, Vol. 38, No. 10, 1992, pp. 2066-2072.

[45] M. Podda, C. Weber, M. G. Traber and L. Packer, "Simultaneous Determination of Tissue Tocopherols, Tocotrienols, Ubiquinols, and Ubiquinones," Lipid Research, Vol. 37, No. 4, 1996, pp. 893-901.

[46] T. H. Kao, Y. F. Lu and B. H. Chen, "Preparative Column Chromatography of Four Groups of Isoflavones from Soybean Cake," European Food Research Technology, Vol. 221, No. 3-4, 2005, pp. 459-465. doi:10.1007/s00217-005-1206-4

[47] S. Vielma, G. Virella, A. J. Gorod and M. F. LopesVirella, "Chlamydophila Pneumonia Infection of Human Aortic Endothelial Cells Induces the Expression of FC $\gamma$ receptor II (Fc $\gamma$ RII)," Clinical Immunology, Vol. 104, No. 3, 2002, pp. 265-273. doi:10.1006/clim.2002.5237

[48] Y. H. Chen, S. J. Lin, J. W. Chen, H. H. Ku and Y. L. Chen, "Magnolol Attenuates VCAM-1 Expression in Vitro in TNF- $\alpha$-Treated Human Aortic Endothelial Cells and in Vivo in the Aorta of Cholesterol-Fed Rabbits," British Journal of Pharmacology, Vol. 135, No. 1, 2002, pp. 37-47. doi:10.1038/sj.bjp.0704458

[49] L. Wang, Y. C. Tu, T. W. Lian, J. T. Hung, J. H. Yen and
M. J. Wu, "Distinctive Antioxidant and Antiinflammatory Effects of Flavonols," Journal of Agricultural and Food Chemistry, Vol. 54, No. 26, 2006, pp. 9798-9804. doi:10.1021/jf0620719

[50] J. A. McCrohon, W. Jessup, D. J. Handelsman and D. S. Celermajer, "Androgen Exposure Increases Human Monocyte Adhesion to Vascular Endothelium and Endothelial Cell Expression of Vascular Cell Adhesion Molecule-1," Circulation, Vol. 99, No. 17, 1999, pp. 2317-2322. doi:10.1161/01.CIR.99.17.2317

[51] J. Rutishauser, "The Role of Statins in Clinical MedicineLDL-Cholesterol Lowering and Beyond," Swiss Medical Weekly, Vol. 136, No. 3-4, 2006, pp. 41-49.

[52] F. Balmir, R. Stacck, E. Jeffery, M. D. B. Jimenez, L. Wang and S. M. Potter, "An extract of Soy Flour Influences Serum Cholesterol and Thyroid Hormones in Rats and Hamsters.," Journal of Nutrition, Vol. 126, No. 12, 1996, pp. 3046-3053.

[53] R. Faruqi, C. de la Motte and P. E. DiCorletto, “ $\alpha$-Tocopherol Inhibits Agonist-Induced Monocytic Cell Adhesion to Cultured Human Endothelial Cells," Journal of Clinical Investigation, Vol. 94, No. 2, 1994, pp. 592-600. doi:10.1172/JCI117374

[54] R. A. Parker, T. Sabrah, M. Cap and B. T. Gill, "Relation of Vascular Oxidation Stress, $\alpha$-Tocopherol and Hypercholesterolemia to Early Atherosclerosis in Hamsters," Arteriosclerosis, Thrombosis, and Vascular Biology, Vol. 15 , No. 3, 1995, pp. 349-358.

doi:10.1161/01.ATV.15.3.349

[55] M. B. Ruiz-Larrea, A. Mohan, N. J. Miller, G. P. Bolwell and C. A. Rice-Evans, "Antioxidant Activity of Phytoestrogenic Isoflavones," Free Radical Research, Vol. 26, No. 1, 1997, pp. 63-70. doi:10.3109/10715769709097785

[56] J. Y. A. Lehtonen, H. Adercreutz and P. K. J. Kinnunen, "Binding of Daidzein to Liposomes," Biochimica et Biophysica Acta, Vol. 1285, No. 1, 1996, pp. 91-100. doi:10.1016/S0005-2736(96)00154-X

[57] M. J. Tikkanen and H. Adlercreutz, "Dietary Soy-Derived Isoflavone Phytoestrogens. Could They Have a Role in Coronary Disease Prevention?" Biochemical Pharmacology, Vol. 60, No. 1, 2000, pp. 1-5. doi:10.1016/S0006-2952(99)00409-8

[58] H. Esterbauer, G. Striegl, H. Puhl, S. Oberreither, M. Rotheneder, M. El-Saadani and G. Jurgens, "The Role of Vitamin E Consumption and the Caroteniods in Preventing Oxidation of Low Density Lipoprotein," Annals of the New York Academy of Sciences, Vol. 570, No. 1, 1989, pp. 254-267. doi:10.1111/j.1749-6632.1989.tb14925.x

[59] A. V. Rao and S. Agarwal, "Bioavailability and in Vivo Antioxidant Properties of Lycopene from Tomato Products and Their Possible Role in the Prevention of Cancer," Nutrition and Cancer, Vol. 31, No. 3, 1998, pp. 199-203. doi:10.1080/01635589809514703

[60] L. B. Tijburg, S. A. Wiseman, G. W. Meijer and J. A. Weststrate, "Effects of Green Tea, Black Tea and Dietary Lipophilic Antioxidants on LDL Oxidizability and Atherosclerosis in Hypercholesterolaemic Rabbits," Atherosclerosis, Vol. 135, No. 1, 1997, pp. 37-47. 
doi:10.1016/S0021-9150(97)00139-1

[61] T. L. Yang, F. Y. Lin, Y. H. Chen, J. J. Chiu, M. S. Shiao, C. S. Tsai, S. J. Ling and Y. L. Chen, "Salvianolic Acid B Inhibits Low-Density Lipoprotein Oxidation and Neointimal Hyperplasia in Endothelium-Denuded Hypercholesterolaemic Rabbits," Journal of Agricultural and Food Chemistry, Vol. 91, No. 1, 2011, pp. 134-141. doi: $10.1002 /$ jsfa. 4163

[62] K. Yoshikura and Y. Hamaguchi, "Anthocyanins of the Black Soybean," Eiiyo to Shohuryo, Vol. 22, No. 6, 1969 , pp. 367-371. doi:10.4327/jsnfs 1949.22.367

[63] A. J. Lusis, "Atherosclerosis," Nature, Vol. 407, No. 6801, 2000, pp. 233-241. doi:10.1038/35025203

[64] C. Gerard and B. J. Rollins, "Chemokines and Disease," Nature Immunology, Vol. 2, No. 2, 2001, pp. 108-115. doi:10.1038/84209

[65] T. Koga and M. Meydani, "Effect of Plasma Metabolites of (+)-Catechin and Quercetin on Monocyte Adhesion to Human Aortic Endothelial cells," American Journal of Clinical Nutrition, Vol. 73, No. 5, 2001, pp. 941-948.

[66] C. Meng, P. Somers, L. Hoong, X. Zheng, Z. Ye, K. Worsencroft, J. Simpson, M. Hotema, M. Weingarten, M. MacDonald, R. Hill, E. Marino, K. Suen, J. Luchoomun, C. Kunsch, L. Landers, D. Stefanopoulos, R. Howard, C. Sundell, U. Saxena, M. Wasserman and L. Sikorski, "Discovery of Novel Phenolic Antioxidants as Inhibitors of Vascular Cell Adhesion Molecule-1 Expression for Use in Chronic Inflammatory Diseases," Journal of Medicinal Chemistry, Vol. 47, No. 25, 2004, pp. 6420-6432. doi:10.1021/jm049685u

[67] P. E. McGregor, D. K. Agrawal and J. D. Edwards, "Attenuation of Human Leukocyte Adherence to Endothelial Cell Monolayers by Tyrosine Kinase Inhibitors," Biochemical and Biophysical Research Communications, Vol. 198, No. 1, 1994, pp. 359-365. doi:10.1006/bbrc.1994.1050

[68] C. Weber, E. Negrescu, W. Erl, A. Pietsch, M. Frankenberger, H. W. Ziegler-Heitbrock, W. Siess and P. C. Weber, "Inhibitors of Protein Tyrosine Kinase Suppress TNF-Stimulated Induction of Endothelial Cell Adhesion Molecules," Journal of Immunology, Vol. 155, No. 1, 1995, pp. 445-451.

[69] M. J. May, C. P. Wheeler-Jones and J. D. Pearson, "Effects of Protein Tyrosine Kinase Inhibitors on CytokineInduced Adhesion Molecule Expression by Human Umbilical Vein Endothelial Cells," British Journal of Pharmacology, Vol. 118, No. 7, 1996, pp. 1761-1771. doi:10.1111/j.1476-5381.1996.tb15602.x

[70] E. Majewska, E. Paleolog, Z. Baj, U. Kralisz, M. Feldmann and H. Tchorzewski, "Role of Tyrosine Kinase Enzymes in TNF-alpha and IL-1 Induced Expression of ICAM-1 and VCAM-1 on Human Umbilical Vein Endothelial Cells," Scandinavian Journal of Immunology, Vol. 45, No. 4, 1997, pp. 385-392. doi:10.1046/j.1365-3083.1997.d01-412.x

[71] C. Weber, "Involvement of Tyrosine Phosphorylation in
Endothelial Adhesion Molecule Induction," Immunology Research, Vol. 15, No. 1, 1996, pp. 30-37. doi:10.1007/BF02918282

[72] S. J. Chinta, A. Ganesan, P. Reis-Rodrigues, G. J. Lithgow and J. K. Andersen, "Anti-Inflammatory Role of the Isoflavone Diadzein in Lipopolysaccharide-Stimulated Microglia: Implications for Parkinson's Disease," Neurotoxicity Research, Vol. 23, No. 2, 2013, pp. 145-53. doi:10.1007/s12640-012-9328-5

[73] B. K. Chacko, R. T. Chandler, A. Mundhekar, N. Khoo, H. M. Pruitt, D. F. Kucik, D. A. Parks, C. G. Kevil, S. Barnes and R. P. Patel, "Revealing Anti-Inflammatory Mechanisms of Soy Isoflavones by Flow: Modulation of Leukocyte Endothelial Cell Interactions," American Journal of Physiology-Heart and Circulatory Physiology, Vol. 289, No. 2, 2005, pp. H908-H915. doi:10.1152/ajpheart.00781.2004

[74] B. Madan, S. B. Batra and B. Ghosh, '2'-Hydroxychalcone Inhibits Nuclear Factor-Kappa B and Blocks Tumor Necrosis Factor-Alpha- and Lipopllysaccharde-Induced Adhesion of Neutropophils to Human Umbilical Vein Endothelial Cells," Molecular Pharmacology, Vol. 58, No. 3, 2000, pp. 526-534.

[75] B. Madan, W. N. Gade and B. Ghosh, "Curcuma Longa Acticates NF-KappaB and Promotes Adhesion of Neutrophils to Human Umbilical Vein Endothelial Cells," Journal of Ethnopharmacology, Vol. 75, No. 1, 2001, pp. 2532. doi:10.1016/S0378-8741(00)00386-X

[76] T. J. Kalogeris, C. G. Kevil, F. S. Laroux, L. L. Coe, T. J. Phifer and J. S. Alexander, "Differential Monocyte Adhesion and Adhesion Molecule Expression in Venous and Arterial Endothelial Cells," American Journal of Physiology, Vol. 276, No. 1, 1999, pp. L9-L19.

[77] A. C. van der Wal and A.E. Becker, "Atherosclerotic Plaque Rupture-Pathologic Basis of Plaque Stability and Instability," Cardiovascular Research, Vol. 41, No. 2, 1999, pp. 334-344. doi:10.1016/S0008-6363(98)00276-4

[78] A. B. Lentsch and P. A. Ward, "Regulation of Inflammatory Vascular Damage," Journal of Pathology, Vol. 190, No. 3, 2000, pp. 343-348. doi:10.1002/(SICI)1096-9896(200002)190:3<343::AID-P ATH522>3.0.CO;2-M

[79] V. Garcia-Mediavilla, I. Crespo, P. S. Collado, A. Esteller, S. Sánchez-Campos, M. J. Toñon and J. González-Gallego, "The Anti-Inflammatory Flavones Quercetin and Kaempferol Cause Inhibition of Inducible Nitric Oxide Synthase, Cyclooxygenase-2 and Reactive C-Protein, and DownRegulation of the Nuclear Factor KappaB Pathway in Chang Liver Cells," European Journal of Pharmacology, Vol. 557, No. 2-3, 2007, pp. 221-229. doi:10.1016/j.ejphar.2006.11.014

[80] S. W. Min, S. N. Ryu and D. H. Kim, "Anti-Inflammatory Effects of Black Rice, Cyaniding-3-O- $\beta$-D-Glycoside, and Its Metabolites, Cyanidin and Protocatechuic Acid," International Immunopharmacology, Vol. 10, No. 8, 2010, pp. 959-966. doi:10.1016/j.intimp.2010.05.009 